\title{
Carbon Estimation and Offsets for U.S. University Aviation Programs
}

\author{
Mary E. Johnson, Alan Gonzalez, Brian Kozak, and Lauren Sperlak
}

Purdue University

\begin{abstract}
Aviation activities produce carbon. The International Civil Aviation Organization has included a carbon calculator on its website as a way to estimate a passenger's carbon footprint. United Airlines, Delta Airlines and British Airways are three airlines that offer customers ways to offset the carbon emissions generated by their air travel. University flight programs also generate carbon emissions. While not required in the United States at this time, forward-thinking companies and universities are looking for ways to reduce their carbon footprint by reducing or offsetting emissions created by combustion of fuels. This paper discusses aviation fuel emissions, examines the carbon footprint of a university flight program, identifies ways to offset the carbon, and explores the use of trees to offset the carbon generated by flight operations. In addition, this paper presents a methodology for estimating the carbon footprint for the fuel used in a university flight training program and for estimating the number of trees to offset aviation emissions.
\end{abstract}

\section{Introduction}

The combustion of aviation gasoline and jet fuel results in carbon emissions. The Environmental Protection Agency (EPA) and the European Environmental Agency agree that carbon emissions have detrimental effects on the environment (EPA, 2012; European Environment Agency, 2012). This paper presents a method for estimating carbon emissions generated by a university flight program and introduces the possible use of trees as a method for offsetting the carbon.

Carbon offsets and caps have not been established in the United States as of 2012, but the European Union (EU) has implemented the Emissions Trading Scheme (ETS) for commercial aviation beginning in January 2012. The U.S. Government submitted the Aviation Greenhouse Gas Emissions Reduction Plan to International Civil Aviation Organization (ICAO) in June 2012 (FAA, 2012). This plan states that the U.S. has a “...goal of achieving carbon-neutral growth for U.S. commercial aviation by 2020 , using 2005 emissions as a baseline" (FAA, 2012, p.1).

While not required in the U.S. at this time, forward-thinking companies and universities are looking for ways to reduce their carbon footprint. United Airlines, Delta Airlines and British Airways are just three airlines that offer customers ways to offset the carbon emissions generated by their air travel. In addition, CalAir Aviation, LLC, a commercially operated flight school located at the Torrance Airport in California, has begun offering carbon offsets and uses donations to carbonfund.org to offset pilot and student flights (Kelly, 2011; CalAir Aviation, LLC,2010). This paper discusses aviation emissions estimation, emission reduction methods, carbon credit and offset methods, and certification. In addition, this paper presents a methodology for estimating the carbon 
footprint for the fuel used in a university flight training program and for estimating the number of trees to offset aviation emissions.

\section{Literature Review}

Air transportation is essential for the quick, safe and cost effective movement of both people and cargo around the world. Aviation activities such as flight, ground operations, brake dust, and terminal operations generate carbon emissions. While this paper focuses on flight operations, the methods described may be used to better understand the offset of carbon generated by other activities on and off airports. Carbon dioxide $\left(\mathrm{CO}_{2}\right)$ is identified as a greenhouse gas (GHG) that has adverse effects on the earth's environment (EPA, 2012; European Environment Agency, 2012). The combustion of currently available aviation fuels, such as Jet A and aviation gasoline, generate carbon emissions. The EU has established the ETS as a way to encourage the reduction of carbon emissions. As previously state, starting in January 2012, flights to or from EU cities have been subject to the ETS, even when the flight originates or ends outside the EU (European Commission, 2012a). While aviation activities within the U.S. are not currently under an ETS, the ICAO is working on a global version of an ETS (ICAO, 2011). This literature review covers aviation emissions, carbon calculation for flight, carbon markets, aviation carbon emissions and offsets, and carbon certification.

\section{Aviation Emissions}

When aviation fuels are combusted in engines, both gaseous and particulate emissions are produced. These emissions include $\mathrm{CO}_{2}$, nitrogen oxides $\left(\mathrm{NO}_{\mathrm{x}}\right)$, sulfur oxides $\left(\mathrm{SO}_{\mathrm{x}}\right)$, carbon monoxide (CO), water vapor, volatile organic compounds (VOC), particulate matter (PM), and other trace gases (see Figure 1). In carbon calculations for emissions trading and offsets, emissions are converted to $\mathrm{CO}_{2}$ equivalents using a global warming potential (GWP) factor that represents the relative amount of warming effect on the atmosphere (International Panel on Climate Change, 2006). In GWP, the emissions are converted using $\mathrm{CO}_{2}$ as the base, and other emissions as a factor of the base. For instance, methane $\left(\mathrm{CH}_{4}\right)$ has a GWP factor of 21 , which means that methane as a GHG is 21 times more capable of trapping heat in the atmosphere than $\mathrm{CO}_{2}$ (EPA, 2011). Aviation programs in the U.S. primarily use aviation gasoline (avgas) powered aircraft, and others use a combination of avgas and jet fuel powered aircraft.

Jet A is a kerosene-based fuel, similar to diesel fuel, which is used in turbine engines. Lead is not added to Jet A; therefore, Jet A emissions do not contain lead. Jet A does, however, contain trace amounts of sulfur which results in $\mathrm{SO}_{\mathrm{x}}$ (Air Transport Action Group, 2011). In comparison, air consists of $79 \%$ nitrogen, $21 \%$ oxygen and less than $1 \%$ other gases (EPA, 2010. The oxygen in the atmosphere is used in combustion. The combustion of Jet A inside a turbine engine with air yields a large amount of energy and emissions consisting of approximately $70 \% \mathrm{CO}_{2}, 25 \%$ water vapor, and less than $5 \%$ of $\mathrm{NO}_{\mathrm{x}}, \mathrm{CO}, \mathrm{VOC}, \mathrm{PM}$ and $\mathrm{SO}_{\mathrm{x}}(\mathrm{FAA}, 2005)$ as summarized in Figure 1. Jet $\mathrm{A}$ is the primary jet fuel used in the United States. However, Jet A-1, which is predominately used outside of the U.S., has similar emissions to Jet A, and is therefore treated as such. 


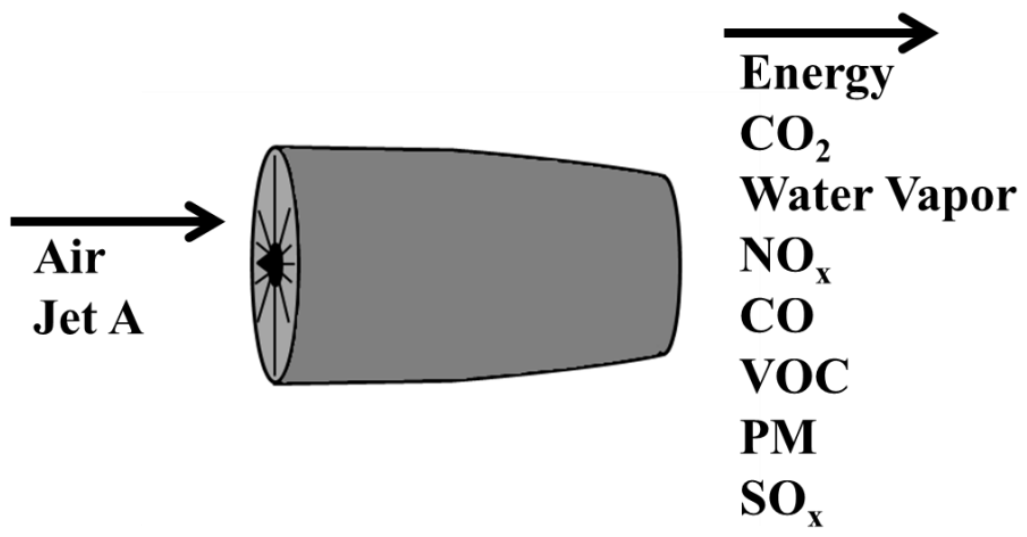

Figure 1. Typical emissions for an aircraft turbine engine.

Aviation gasoline in the U.S. is 100 low lead, which is similar to high-octane automotive gasoline. Unlike jet fuel, lead is added during the petroleum refining process for avgas, therefore lead is in the emissions. The combustion of avgas in aircraft piston engines produces approximately the mixture and percentages of emissions as turbine engines, except for the addition of lead (FAA, 2005).

\section{Carbon Calculation for Flight}

The EU ETS seeks to reduce carbon emissions through a carbon allocation and offset system based on the cap and trade principle (European Commission, 2012b). While applicable to EU heavy industries since 2005, the EU ETS began covering aviation activities beginning in January 2012 (European Commission, 2012a). The EU has delayed the implementation of the ETS for non-EU airlines until next year; however, the ETS is still in effect for airlines within the EU. Each metric ton $(1,000 \mathrm{~kg})$ of carbon dioxide is equivalent to one carbon credit. Simply put, the EU ETS method estimates the amount of carbon based on the amount of fuel consumed on flights in to and out of the EU (European Commission, 2012a). The legality of the EU ETS was upheld in the European courts in December 2011 (European Commission, 2012a). However, the legality of the EU ETS is being challenged by countries and airlines across the globe such as the U.S., China and India (Buyck, 2011; Trauvetter, 2012; Moores, 2012). The EU has made estimation of carbon simple by basing it on the amount of fuel consumed (European Commission, 2010b). In the EU ETS, carbon may be calculated by multiplying the kilograms of fuel consumed by the emissions factor of $3.15 \mathrm{~kg}-\mathrm{CO}_{2} / \mathrm{kg}$ fuel for Jet A/A-1 and by the emissions factor of $3.10 \mathrm{~kg}-\mathrm{CO}_{2} / \mathrm{kg}$-fuel for aviation gasoline as described in Chapters 1 and 3 of the IPCC Guidelines for National Greenhouse Gas Inventories (International Panel on Climate Change, 2006). The U.S. Environmental Protection Agency publishes emission factors for aviation gasoline as $8.31 \mathrm{lb}-\mathrm{CO}_{2} /$ gallon and for jet fuel as $9.75 \mathrm{lb}-\mathrm{CO}_{2} /$ gallon (EPA, 2011).

The ICAO publishes a Carbon Emissions Calculator that provides an estimate of the carbon footprint or carbon emissions per traveler on specific air routes throughout the world, and uses factors such as aircraft types, cabin class seating, and load factor. By identifying the cabin class seating, number of passengers, one-way or round trip, and city 
pairs, the calculator estimates the kilograms of $\mathrm{CO}_{2}$ per passenger, and shows the typical aircraft types on the route, average kilograms of fuel consumed, and average number of seats per flight. The full ICAO methodology for calculating carbon footprint is available (ICAO, 2012b). For instance, one passenger flying round trip with an economy class ticket from New York (JFK) to Frankfurt, Germany (FRA) results in $821.86 \mathrm{~kg}$ of $\mathrm{CO}_{2}$ estimated using the ICAO carbon calculator on the website (ICAO, 2012a). The ICAO calculator uses the jet fuel emission factor of $3.157 \mathrm{~kg}-\mathrm{CO}_{2} / \mathrm{kg}$-fuel and is intended for use by jet aircraft travelers in carbon offset programs (ICAO, 2012b). The ICAO calculator is not the only calculator used by airlines. International Air Transport Association (IATA) reported that 32 member airlines have carbon calculators to offset emissions from flight using projects of varying qualities (Schneider, 2012).

\section{Carbon Markets}

The United Nations Framework Convention on Climate Change (UNFCCC) was created in 1992 to evaluate solutions against climate change; and in 1997 the Kyoto Protocol was adopted by the UNFCCC to reinforce inadequate resolutions from the first Convention (UNFCCC, 2012). In the Kyoto Protocol, targets were established for GHG emissions for 37 countries and the European Union. These nations are obligated to reduce their GHG emissions, and the developed nations must reduce GHG at a proportionally higher rate than developing nations (UNFCCC, 2012a).

To help achieve emission targets, the Kyoto Protocol created three market-based mechanisms, resulting in a regulated carbon market: Emissions Trading System (ETS), the Clean Development Mechanism (CDM), and Joint Implementation (JI) (UNFCCC, $2012 \mathrm{~b}$ ). The biggest carbon markets around the world such as the European Union use the ETS (Brohe, Eyre, \& Howarth, 2009). Emission Trading Systems work under a cap and trade or a baseline and credit (Brohe, et al., 2009). The carbon market is a key tool for reducing emissions worldwide; it was worth 30 billion U.S. dollars in 2006 and is growing (UNFCCC, 2012b). As of October 2012, the United States has not ratified the Kyoto Protocol that it signed in December 11, 1998 (UNFCCC, 2006). This means any projects to offset U.S. aviation emissions will fall into the voluntary carbon markets.

In the voluntary offsetting carbon markets, an institution estimates their GHG emissions and proposes to offset emissions from a different institution at a certain price per metric ton (Brohe, et al., 2009). The offset provider sets a price to offset emissions at a certain price per metric ton or carbon credit. Offset prices for credits are dependent on which of fiver project types are used: "forestry, renewable energy, destruction of fluorinated gases, and energy efficient projects related to waste management or recovery of methane" (Brohe, et al., 2009, p 275). The voluntary carbon market may be of interest to university aviation programs. This paper focuses on university-based aviation programs located in the United States. The authors believe that the EU ETS is not expected to affect U.S.-based university aviation operations. 


\section{Aviation Carbon Reduction and Offset Methods}

Current technology for commercial air travel and university-based flight training programs requires the use of fuel that emits carbon, most commonly avgas and Jet A. Decreasing fuel consumption is one way to decrease carbon emissions. In addition, the U.S. government has identified five other ways to reduce carbon emissions: technological improvement of engines and aircraft, improvements in operations, alternative fuels, scientific modeling and analysis, and policies, standards and measures that support carbon neutral growth (FAA, 2012). Operational changes may include routing considerations (Johnson \& Gonzalez, in press), approach paths, single engine taxi, or other changes. The carbon emitted by air transportation may be offset. Aviation businesses are offering ways for customers to offset their carbon footprint. First, airline offset programs are introduced, and then a commercial flight school offset program is described.

Airlines around the world are currently participating in voluntary and carbon offset programs approved by the UNFCCC. IATA's program for TAP, a Portuguese airline, has begun replacing fossil fuel-based electricity generators with hydropower electricity generators with an expected GHG reduction of nearly 15,000 metric tons of $\mathrm{CO}_{2}$ equivalent each year (IATA, 2012). Airlines are also offering ways for travelers to offset their carbon through voluntary aviation emissions offset programs. Of the 30 airlines offering carbon offsets (ICAO, 2010), three airline examples are discussed: Delta, United, and British Airways. Delta Airlines claims being the first airline to offer a carbon offset option for purchasers of air tickets beginning in 2007 (Delta Airlines, 2012). Using Delta's online emissions calculator, travelers may purchase carbon offsets that currently support a Nature Conservancy forestry management project in Belize (Delta Airlines, 2012). The Nature Conservancy has a carbon footprint calculator available on its website that uses a $\$ 15$ gifts to offset one metric ton of $\mathrm{CO}_{2}$ (Nature Conservancy, 2012). Using the Nature Conservancy calculator, one roundtrip flight of over 300 miles each way is estimated to have an impact of 2.2 metric tons and costs $\$ 30$ to offset.

United Airlines has a carbon offset program titled eco-skies that offers carbon offsets for $\$ 5$ per 0.5 metric ton or donation to a specific carbon project (United Airlines, 2012). Using the United Airlines calculator for a round trip flight from New York (JFK) to Paris (CDG) in October, the estimated carbon footprint was 1.5 metric tons. The two programs offered on the United Airlines website were a $\$ 30.30$ donation to a forest conservation project in California or a $\$ 15.15$ donation to a wind power project in Texas (United Airlines, 2012). For British Airways, passengers may choose to donate money to the One Destination Carbon Fund that supports projects in the United Kingdom (British Airways, 2012). A carbon offset calculator was not found on the British Airways website.

At least one commercial flight school is offering a program to offset the carbon footprint of flight training. The school makes contributions to a carbon offset program based on fuel consumption during pilot training (CalAir Aviation, LLC, 2012; Kelly, 2011). The chosen offset program is carbonfund.org (Kelly, 2011) which uses donations of approximately $\$ 10$ per metric ton to support third-party offset projects. 


\section{Carbon Certification}

Certification of carbon offset programs is a concern. The IATA has voiced concerns regarding validation and certification of offset programs. These concerns include setting and ensuring standards are met, accurate emissions calculations, and transparency of auditable offsets (Schneider, 2012, p. 15). With an offset market of nearly $\$ 400$ million dollars in 2011, fraudulent carbon offsets and credits is a real threat, with several occurrences already (Struck, 2010; Collinson, 2012; \& Russell, 2012). There are certification programs from organizations such as carbonfund.org and carbon neutral plane (Carbonfund.org, n.d.a \& Carbon Neutral Plane, 2012). An international standards body, the International Organization of Standardization, has developed a series of standards under ISO 14000 to address environmental management systems. For instance, there are ISO standards for GHG inventory and reporting, validation and verification of GHG assertions, and accreditation of validation and verification bodies. Table 1 summarizes a portion of the ISO 14000 series standards related to GHG inventories. ISO 14064-3 addresses GHG validation and verification of GHG claims while ISO 14065 contains principles and requirements that bodies seeking validation or verification should be able to conform to (ISO, 2006b).

Table 1

Summary of Selected ISO 14000 Standards

\begin{tabular}{lcl} 
ISO Standard & \multicolumn{1}{c}{ Focus } & \multicolumn{1}{c}{ Purpose } \\
\hline 14001 & Organization & Environmental Management Systems \\
$14064-1$ & Organization & GHG Inventory \& Reporting of Emissions \\
$14064-2$ & Project & GHG Quantification \& Reporting of Emissions \\
$14064-3$ & Claims/Assertion & Validation \& Verification of GHG Assertions \\
14065 & Verification Body & Accreditation of GHG Validation \& Verification \\
14066 & Verification Body & Competence Requirements for GHG Validation \\
& & \& Verification Bodies
\end{tabular}

Note. ( ISO 2006a)(ISO 2006b)

\section{Methodology}

The researchers used the following methodology in this study to determine carbon credits needed by a university-based flight program. First, the amount of jet fuel and amount of aviation gasoline used by the aviation program were estimated. Second, these estimates were used to estimate the amount of carbon generated by flight operations and the amount of carbon credits needed to offset. Third, the number of trees and amount of land was estimated to offset this amount of carbon. Finally, an analysis was performed on the carbon offsets and costs. 


\section{Data}

\section{Estimate Aviation Fuel Consumption}

First, the authors chose to use estimates of 10,000 gallons of Jet A and 10,000 gallons of aviation gasoline in the analysis to facilitate linear scaling of results. While the actual amounts of fuel consumed fluctuate based on the amount and characteristics of flight operations, a constant amount of 10,000 gallons of fuel was used in all years of the analysis for simplicity of method.

\section{Estimate Amount of Carbon and Carbon Credits}

Based on the literature review, the authors have chosen to use both the International Panel on Climate Change (IPCC) emissions factors and the EPA emissions factors in this step. The number of carbon credits required for each year of flight operations at 10,000 gallons of Jet A and 10,000 gallons of avgas are shown in Table 2 for IPCC emissions factors and Table 4 for EPA emissions factors. The formulas to calculate the carbon credits are shown in Table 3 for IPCC and Table 5 for EPA. In addition, simplified forms of the equations are shown using an input of gallons of fuel.

In many situations in the U.S., records of fuel purchased are in gallons. The IPCC formulas use kilograms. The conversion factors for gallons to kilograms are shown in Table 2 and in Table 4 notes. To convert gallons of avgas to pounds, a conversion factor of 6 was used (FAAFSS, 2009). To convert pounds of avgas to kilograms, a conversion factor of 0.45359 was used (EPA, 2004). To convert gallons of Jet A to pounds, a conversion factor of 6.8 was used (FAAFSS, 2009). To convert pound of avgas to kilograms, a conversion factor of 0.45359 was used (EPA, 2004). Each carbon credit represents one metric ton of $\mathrm{CO}_{2}$, therefore, the amount of carbon in kilograms was divided by 1,000 to estimate the number of carbon credits represented (Brohe, A., et al., 2009). The cost of carbon credits was obtained from Intercontinental Exchange (2012). In addition, Table 2 and Table 4 summarize the amount of fuel, amount of carbon credits or carbon in metric tons.

The number of carbon credits required to offset 10,000 gallons of aviation gasoline is 85 for IPCC (from Table 2) and 83 for EPA (from Table 4). The number of carbon credits required to offset 10,000 gallons of jet fuel is 98 (from Table 2) for IPCC and 95 for EPA (from Table 4). In Table 6, estimates for whole numbers of metric tons of $\mathrm{CO}_{2}$ are shown for 10,000 to 100,000 gallons of avgas and for Jet A. These IPCC and EPA carbon credit numbers differ from each other. IATA has also noticed that carbon estimates are not consistent among the 32 member airlines investigated (Scheider, 2012). While these IPCC and EPA carbon credit estimates for avgas are only 2 credits apart at 10,000 gallons, the difference at 100,000 gallons is 20 credits. 
Table 2

Estimated Carbon Emissions for Flight Operations Using IPCC Factors

Fuel Type Gallons of Fuel Used per Year kg of Fuel $^{\mathrm{a}} \quad$ IPCC Factor $^{\mathrm{b}}$ Total $\mathrm{CO}_{2}$ Metric Tons

\begin{tabular}{lllll}
\hline Avgas & 10,000 & 27,215 & 3.10 & 84.4 \\
Jet A & 10,000 & 30,844 & 3.15 & 97.2
\end{tabular}

Note. (Avgas) $\mathrm{kg}$ of fuel $=10,000$ gallons $* 6 \mathrm{lb} / \mathrm{gallon} * 0.45359 \mathrm{~kg} / \mathrm{lb}=27,215 \mathrm{~kg}$

(Jet A) $\mathrm{kg}$ of fuel $=10,000$ gallons $* 6.8 \mathrm{lb} / \mathrm{gallon} * .45359 \mathrm{~kg} / \mathrm{lb}=30,527 \mathrm{~kg}$

$($ Avgas $) \mathrm{CO}_{2}$ (Metric Tons $)=(27,306 \mathrm{~kg} * 3.10) / 1,000=84.4$ Metric Tons of $\mathrm{CO}_{2}$

(Jet A) $\mathrm{CO}_{2}$ (Metric Tons) $=(30,527 \mathrm{~kg} * 3.15) / 1,000=97.2$ Metric Tons of $\mathrm{CO}_{2}$

${ }^{\mathrm{a}}$ FAAFSS (2009). ${ }^{\mathrm{b}}$ Maurice, Hockstad, Höhne, Hupe, Lee, Rypdal (2006).

Table 3

Carbon Credit Worksheet Using IPCC Factors

Fuel Gallons $\quad \mathrm{lbs}_{\mathrm{gal}} \mathrm{a}^{\mathrm{a}} \quad \mathrm{kg} / \mathrm{lbs} \quad$ IPCC Factor $^{\mathrm{b}} \mathrm{kg} /$ Metric ton Carbon Credits

\begin{tabular}{|c|c|c|c|c|c|c|c|c|c|}
\hline Avgas & $*$ & 6 & $*$ & $1 / 2.2$ & $*$ & 3.10 & I & 1,000 & $=$ \\
\hline Jet A & $*$ & 6.8 & $*$ & $1 / 2.2$ & $*$ & 3.15 & 1 & 1,000 & $=$ \\
\hline
\end{tabular}

Simplified Formula

Fuel

Gallons

Simplified Factor

Carbon Credits

Avgas

Jet A

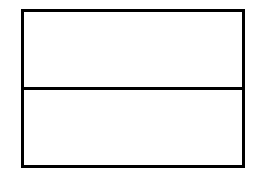

$*$

0.00845

$*$

0.00974

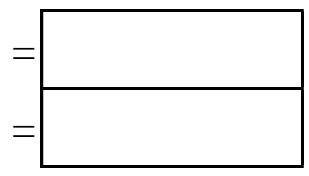

Note. ${ }^{\mathrm{a}}$ FFAFSS (2008). ${ }^{\mathrm{b}}$ Maurice et al. (2006). 
Table 4

Estimated Carbon Emissions for Flight Operations Using EPA Factors

\begin{tabular}{|c|c|c|c|}
\hline Fuel Type & Gallons of Fuel Used per Year & EPA Factor ${ }^{\mathrm{a}}$ & Total $\mathrm{CO}_{2} \mathrm{M}$ \\
\hline
\end{tabular}

\begin{tabular}{llll}
\hline Avgas & 10,000 & 8.31 & 83.1 \\
Jet A & 10,000 & 9.75 & 97.5
\end{tabular}

Note. (Avgas) Total $\mathrm{CO}_{2}$ (Metric Tons $)=(10,000 * 8.31) / 1,000=83.1$

(Jet Fuel) Total $\mathrm{CO}_{2}$ (Metric Tons) $=(10,000 * 9.75) / 1,000=94.8$

${ }^{\mathrm{a}} \mathrm{EPA}(2011)$.

Table 5

Carbon Credit Worksheet Using EPA Factors

$\begin{array}{llll}\text { Fuel Gallons } & \text { EPA Factor } & \text { Carbon Credits }\end{array}$

\begin{tabular}{lllllll|} 
Avgas & & $*$ & 8.31 & $/$ & 1,000 & $=$ \\
\cline { 5 - 6 } Jet A & 9.75 & $/$ & 1,000 & $=$
\end{tabular}

Formula Simplified

Fue

Gallons

Simplified Factor

Carbon Credits

Avgas

Jet A

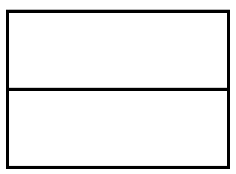

$*$

0.00831

$*$

0.00975

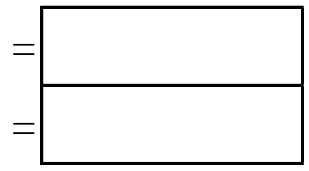

Note. ${ }^{\mathrm{a}} \mathrm{EPA}$ (2011). 
Table 6

Metric Tons of $\mathrm{CO}_{2}$ Using IPCC and EPA Factors

\begin{tabular}{lcc} 
Fuel & $\begin{array}{c}\text { Avgas } \\
\mathrm{IPCC} \mathrm{CO}_{2}\end{array}$ & $\mathrm{EPA} \mathrm{CO}_{2}$ \\
\hline 10,000 & 85 & 83 \\
20,000 & 169 & 166 \\
30,000 & 254 & 249 \\
40,000 & 338 & 332 \\
50,000 & 422 & 416 \\
100,000 & 844 & 831
\end{tabular}

$\underline{\text { Jet A }}$

\begin{tabular}{lcc} 
Fuel & $\mathrm{IPCC} \mathrm{CO}_{2}$ & $\mathrm{EPACO}_{2}$ \\
\hline 10,000 & 98 & 98 \\
20,000 & 195 & 195 \\
30,000 & 292 & 293 \\
40,000 & 389 & 390 \\
50,000 & 486 & 488 \\
100,000 & 972 & 975
\end{tabular}

Note. Numbers are rounded up to the next whole metric ton (1 metric ton is approximately 2,200lbs). Avgas and Jet A numbers in gallons.

\section{Estimate the Offsets}

The amount of carbon dioxide offsets needed is determined by the amount of carbon dioxide produced per year through the consumption of fuel. As shown in Table 6, the number of carbon credits required to offset 10,000 gallons of aviation gasoline is 85 for IPCC emissions factors and 83 for EPA emissions factors. The number of carbon credits required to offset 10,000 gallons of jet fuel is 98 for IPCC emissions factors and 95 for EPA emissions factors. In this discussion, the EPA estimates are used. To offset 83 metric tons using donations to carbonfund.org would cost $\$ 830$ at $\$ 10$ per metric ton (carbonfund.org, n.d.b). In addition, carbonfund.org offers trees for sale to offset carbon at $\$ 1$ per tree, but do not specify the number of metric tons offset by trees.

The Energy Information Administration within the U.S. Department of Energy has provided a method for estimating carbon sequestration in trees (EIA, 1998). The amount of carbon dioxide absorbed is dependent upon the type of tree, how fast it grows and the trees survival rate. Fast-growing species of hardwood trees, such as yellow poplar, red 
oak, elm and white ash offer the best combination of carbon dioxide sequestration and survival rate (EIA, 1998). Calculations for carbon sequestration are based upon 680 trees per acre, which is the ideal spacing for reforestation (SCFC, n.d.). In these calculations, based on South Carolina Forestry Commission (SCFC) information, the 6,800 trees are planted are in a 15-gallon container or balled and burlapped spaced evenly over a 10acre plot. Year 0 represents the year that the trees are planted. At planting, the SCFC estimates that only $87.3 \%$ of the original 6,800 trees planted will survive. In year 6 , the number of surviving trees will be roughly 4,346 (EIA, 1998). Therefore, if 10 acres of trees are planted, it would only take 6 years for the trees to sequester enough carbon dioxide to offset the amount produced from the combustion of 10,000 gallons of avgas, as demonstrated in Table 7. These calculations in Table 7 are dependent on the number of trees planted per acre. Other combinations of tree type, tree size at planting, and density of trees planted per acre will alter the results.

\section{Carbon Offsets and Costs}

Estimating aviation emissions offsets and costs may be done in at least two different ways. One way is to purchase certified offsets recognized by the pertinent regulatory bodies. Another way is to develop an offset program. For instance, carbonfund.org offers carbon offsets at $\$ 10$ per metric ton or trees at one dollar each for an unspecified amount of carbon (carbonfund.org, n.d.b). If a flight program chooses to develop their own offset program using newly planted trees, then for every 10,000 gallons of avgas consumed each year, 6,800 fast growing hardwood trees would need to be planted on 10 acres of land. The selection of tree type would be based on the climate and soil conditions were planted. Using the rates of carbon sequestration by the trees and the percentages of surviving trees, this research shows that at least 86 carbon credits are generated per year after year 6. No costs for land, trees, planting, or maintenance of the trees are included in this analysis; therefore, no cost per carbon credit generated is provided in the analysis. These costs for implementation and maintenance are not included due to several factors including fluctuation of costs over time and regions; regional variations in land, labor, trees, equipment and material costs; the types of trees appropriate for different regions; fertilizer and pesticide costs; regional climate differences; and other agricultural risk factors. In addition to these two ways to offset carbon, other ways to offset emissions may be forthcoming in future ETS programs. 
Table 7

$\mathrm{CO}_{2}$ Sequestration Evaluation of 6,800 Fast Growing Hardwood Trees

\begin{tabular}{lcccccc} 
Year & Survival & $\begin{array}{c}\text { Pounds of Carbon per } \\
\text { Tree per Year }\end{array}$ & $\begin{array}{c}\text { Trees } \\
\text { Planted }\end{array}$ & $\begin{array}{c}\mathrm{CO}_{2} \mathrm{lbs} \text { per } \\
\text { year }\end{array}$ & $\begin{array}{c}\mathrm{CO}_{2} \mathrm{~kg} \text { per } \\
\text { year }\end{array}$ & $\begin{array}{c}\text { Carbon Credit } \\
\text { per year }\end{array}$ \\
\hline 0 & $87.3 \%$ & 2.7 & 5,937 & 58,824 & 26,738 & 26.7 \\
1 & $79.8 \%$ & 4.0 & 5,427 & 79,660 & 36,209 & 36.2 \\
2 & $73.6 \%$ & 5.4 & 5,005 & 99,185 & 45,084 & 45.1 \\
3 & $70.6 \%$ & 6.9 & 4,801 & 121,571 & 55,259 & 55.3 \\
4 & $67.8 \%$ & 8.5 & 6,611 & 143,821 & 65,373 & 65.4 \\
5 & $65.8 \%$ & 10.1 & 4,475 & 165,853 & 75,388 & 75.4 \\
6 & $63.9 \%$ & 11.8 & 4,346 & 188,173 & 85,533 & 85.5 \\
7 & $62.1 \%$ & 13.6 & 4,229 & 210,768 & 95,804 & 95.8
\end{tabular}

Note. Information is based on 10 acres of land and initial 6,800 hardwood trees planted.

\section{Results}

An aviation program consuming 10,000 gallons of avgas per year would produce an estimated 83 metric tons of carbon dioxide using EPA emissions factors. Using offset projects from organizations such as carbonfund.org, the carbon offset would cost $\$ 10$ per metric ton or $\$ 830$. Using trees as a way to offset the carbon dioxide for 10,000 gallons of avgas per year, a flight program would need to start 6,800 fast growing hardwood trees in 15-gallon containers planted on 10 acres of land. In the regulatory carbon market, prices fluctuate over time; on the other hand, in the voluntary markets, prices depend on the project costs itself. (Brohe, et al., 2009). Currently, carbon credits from domestic reforestation projects can only be traded in the voluntary markets, due to a non-existent regulatory market in the U.S. It is essential that carbon measurements are reliable and valid so that one carbon credit is equivalent to any other around the world (Brohe, et al., 2009).

\section{Discussion and Conclusion}

In the U.S., limitations on the amount of carbon emissions are not imposed on aviation activities as of February 2013. The EU started to regulate aviation carbon emissions on January 1, 2012 for flights originating or landing at an EU airport, even those flights that extend beyond EU borders. ICAO is studying the EU's carbon trading scheme and investigating alternative methods to limit aviation carbon on a global basis. Therefore, the EU delayed implementation of the EU ETS on flights to or from the EU on non-EU airlines. The authors believe that it is only a matter of time before aviation activities in the U.S. and North America are affected by carbon regulation. This article presented carbon offsets that may be purchased from organizations or carbon offsets that may be produced using reforestation projects. Whether these types of offsets may be used to 
offset aviation activities in the U.S. is a question for the regulatory agencies. Offsetting the carbon footprint of aviation may be done through certified projects, and may or may not produce tradable or offsetting carbon credits.

\section{Future Research}

Offsetting carbon emissions is only one way to reduce the carbon footprint of aviation activities. Other ways to reduce the carbon footprint include improvements to fuels, aircraft and procedures that reduce fuel consumption. Future research will explore specific forestation and herbaceous plants as carbon sequestration methods, and specific fuel reduction methods for university-related aviation activities. In addition, future research will explore the total carbon footprint of university aviation activities to include impacts from fuel and other items such as lubricants, paper, electricity usage, and movement of students to and from the campus. 


\section{References}

Air Transport Action Group. (2011). Beginner's guide to aviation biofuels. Retrieved from http://www.atag.org/our-publications/latest.html

British Airways. (2012). One Destination Carbon Fund. Retrieved from http://www.onedestination.co.uk/environment/climate-change/one-destinationcarbon-fund/

Brohe, A., Eyre, N., \& Howarth, N. (2009). Carbon Markets an International Business Guide. London, UK: Earthscan.

Buyck, C. (2011). More Than 20 Countries to Declare Joint Opposition to EU ETS. Retrieved from http://atwonline.com/international-aviation-regulation/news/more20-countries-declare-joint-opposition-eu-ets-1003

CalAir Aviation, LLC. (n.d.). About CalAir, Carbon Free Flight School. Retrieved from http://www.calaironline.com/about.html

Carbonfund.org. (n.d.a). Our mission: Towards a ZeroCarbon world. Retrieved from http://carbonfund.org/about

Carbonfund.org. (n.d.b). Reduce your individual carbon footprint, use our calculators. Retrieved from_http://carbonfund.org/individuals

Carbon Neutral Plane. (2012). Carbon Neutral Plane program. Retrieved from http://www.carbonneutralplane.com/program.html

Collinson, P. (2012, October 13). Money: Hang up on this sickening scam. The Guardian. Retrieved from http://www.lexisnexis.com/lnacui2api/auth/checkbrowser.do?rand=0.56849920589 $27117 \&$ cookieState $=0 \&$ ipcounter $=1 \& b h c p=1$

Delta Airlines. (2012). Improving the Environment. Retrieved from http://www.delta.com/about_delta/global_good/environment/

Energy Information Administration (EIA). (1998). Method for calculating carbon sequestration by trees in urban and suburban setting. Retrieved from ftp://ftp.eia.doe.gov/pub/oiaf/1605/cdrom/pdf/sequester.pdf

Environmental Protection Agency. (2011). Emission Factors for Greenhouse Gas Inventories. Retrieved from http://www.epa.gov/climateleadership/documents/emission-factors.pdf

Environmental Protection Agency. (2010.). Pollutants in the Ambient Air. Retrieved from http://www.epa.gov/eogapti1/course422/ap2.html 
Environmental Protection Agency. (2012). Green House Gas Emissions. Retrieved from http://www.epa.gov/climatechange/ghgemissions/gases.html

European Commission. (2012a). Climate Action: Transport Aviation Reducing Emissions from the Aviation Sector. Retrieved from http://ec.europa.eu/clima/policies/transport/aviation/index_en.htm

European Commission. (2012b). Climate Action: Emission Trading System Emission Trading System (EU ETS). Retrieved from http://ec.europa.eu/clima/policies/ets/index_en.htm

European Environment Agency. (2012). Carbon dioxide. Retrieved from http://www.eea.europa.eu/maps/ozone/resources/glossary/carbon-dioxide

Federal Aviation Administration. (2005). Aviation and emissions a primer. Washington DC: Author.

Federal Aviation Administration. (2012). United States Aviation Greenhouse Gas Emissions Reduction Plan, Submitted to the International Civil Aviation Organization, June 2012. Retrieved from http://www.faa.gov/about/office_org/headquarters_offices/apl/environ_policy_guid ance/policy/media/Aviation_Greenhouse_Gas_Emissions_Reduction_Plan.pdf

Federal Aviation Administration Flight Standards Service (FAAFSS). (2009). Pilot's Handbook of Aeronautical Knowledge. Oklahoma City, OK: United States Department of Transportation, Federal Aviation Administration Airman Testing Standards Branch.

International Air Transport Association. (n.d.). Industry carbon offset program. Retrieved from http://www.iata.org/whatwedo/environment/Documents/carbon-offsetsep2010.pdf

International Civil Aviation Organization. (2010). Industry Carbon Offset Program. Retrieved from http://www.iata.org/whatwedo/environment/Documents/carbonoffset-sep2010.pdf

International Civil Aviation Organization. (2011). Guidance Material for the Development of States' Action Plans Towards the Achievement of ICAO's Global Climate Change Goals. Retrieved from http://www.icao.int/environmentalprotection/Documents/GuidanceMaterial_DevelopmentActionPlans.pdf

International Civil Aviation Organization. (2012a). Carbon Emissions Calculator. Retrieved from http://www.icao.int/environmentalprotection/CarbonOffset/Pages/default.aspx 
International Civil Aviation Organization. (2012b). Carbon Emissions Calculator Version 5, June 2012. Retrieved from http://www.icao.int/environmentalprotection/CarbonOffset/Documents/Methodology\%20ICAO\%20Carbon\%20Calcu lator_v5-2012.Revised.pdf

Intercontinental Exchange. (2012). Emissions. Retrieved from https://www.theice.com/productguide/ProductGroupHierarchy.shtml?groupDetail= \&group.groupId=19

International Panel on Climate Change. (2006). IPCC Guidelines for National Greenhouse Gas Inventories Volume 2 Energy. Retrieved from http://www.ipccnggip.iges.or.jp/public/2006gl/vol2.html

ISO (2006a) Standard 14064-2:2006: Greenhouse gases -- Part 2: Specification with guidance at the project level for quantification, monitoring, and reporting of greenhouse gas emission reductions or removal enhancements.

ISO (2006b) Standard 14064-3:2006: Greenhouse gases -- Part 3: Specification with guidance for the validation and verification of greenhouse gas assertion.

Johnson, M. E. \& Gonzalez, A. (in press). Effects of a carbon emissions trading system on aviation financial decisions. Journal of Aviation Technology and Engineering.

Kelly, L. (2011). CalAir Creates Carbon-Neutral Flight Training in LA Area. Carbonfund.org. Retrieved from http://carbonfund.org/blog/item/3812-cal-aircreates-carbonneutral-flight-training-la-south-bay

Moores, V. (2012). ICAO Sees EU ETS as Regional Issue. Air Transport World. Retrieved from http://atwonline.com/international-aviation-regulation/news/icaosees-ets-regional-issue-1001

Nature Conservancy. (2012). Carbon Calculator. Retrieved from http://www.nature.org/greenliving/carboncalculator/index.htm

Russell, J. (2012, June 6). Carbon credit fraud soaring, warns FSA. The Daily Telegraph. Retrieved from http://www.lexisnexis.com/lnacui2api/results/docview/docview.do?docLinkInd=tru e\&risb=21_T15856827096\&format=GNBFI\&sort=BOOLEAN\&startDocNo=26\&r esultsUrlKey=29_T15856830903\&cisb=22_T15856830902\&treeMax =true \&treeWi $\mathrm{dth}=0 \& \mathrm{csi}=8109 \& \mathrm{docNo}=43$

Schneider, M. (2012). Voluntary airline carbon offset programs. Retrieved from http://www.uncsd2012.org/content/documents/743presentationschneider.pdf

South Carolina Forestry Commission (SCFC). (n.d.). Seedling spacing trees per acre. Retrieved from http://www.state.sc.us/forest/nurspa.htm 
Struck, D. (2010, April 20). Buying carbon offsets may ease eco-guilt but not global warming. The Christian Science Monitor. Retrieved from http://www.csmonitor.com/Environment/2010/0420/Buying-carbon-offsets-mayease-eco-guilt-but-not-global-warming

United Airlines, 2012. United's carbon offset program. Retrieved from http://CO2offsets.sustainabletravelinternational.org/ua/offsets/

United Nations Framework Convention on Climate Change. (2012). Background on the UNFCCC: The international response to climate change. Retrieved from http://unfccc.int/essential_background/items/6031.php

United Nations Framework Convention on Climate Change. (2012a). Kyoto Protocol. Retrieved from http://unfccc.int/kyoto_protocol/items/2830.php

United Nations Framework Convention on Climate Change. (2012b). The Mechanisms under the Kyoto Protocol: Emissions Trading, the Clean Development Mechanism and Joint Implementation. Retrieved from http://unfccc.int/kyoto_protocol/mechanisms/items/1673.php

United Nations Framework Convention on Climate Change. (2006). Kyoto Protocol Status of Ratification. Retrieved from http://unfccc.int/files/essential_background/kyoto_protocol/status_of_ratification/ap plication/pdf/kpstats.pdf 